УДК 316.77:[004.738.1:641.5]

\title{
ПАРАМЕТРИ УКРАЇНСЬКОГО КУЛІНАРНОГО САЙТУ: СОЦІАЛЬНО-КОМУНІКАТИВНА СИТУАЦІЯ, КОМУНІКАТИВНА МЕТА, КОНЦЕПЦІї АДРЕСАНТА Й АДРЕСАТА
}

\section{Оксана Остроушко}

\author{
Криворізький державний педагогічний університет \\ Kryvyi Rih State Pedagogical University \\ пр. Гагаріна, 54, Кривий Ріг, 50086, Украӥна \\ ostroushko.oksana@gmail.com
}

Остроушко О. Параметри українського кулінарного сайту: соціальнокомунікативна ситуація, комунікативна мета, концепції адресанта й адресата

У статті розглянуто низку прагматичних параметрів українськомовного кулінарного сайту як особливого жанру в комунікативному просторі Інтернету - своєрідної електронної динамічної кулінарної книги, що побутує в соціально-комунікативній ситуації передачі (поширення) досвіду. Визначено комунікативну мету кулінарних сайтів, виокремлено наміри й інтенції мовців, описано ключові характеристики узагальнених образів адресанта й адресата.

Ключові слова: кулінарний сайт, мовленнєвий жанр, комунікативна мета, адресант, адресат.

Остроушко О. Параметры украинского кулинарного сайта: социальнокоммуникативная ситуация, коммуникативная цель, концепции адресанта и адресата

В статье рассмотрен ряд прагматических параметров украинского кулинарного сайта как особенного жанра в коммуникативном пространстве Интернета - своеобразной электронной динамической кулинарной книги, функционирующей в социально-коммуникативной ситуации передачи (распространения) опыта. Определены коммуникативная цель кулинарных сайтов, намерения и интенции коммуникантов, описаны ключевые характеристики обобщенных образов адресанта и адресата.

Ключевые слова: кулинарный сайт, речевой жанр, коммуникативная цель, адресант, адресат.

Ostroushko O. Parameters of Ukrainian Culinary Sites: SocioCommunicative Situation, Communicative Purpose, Concepts of Narrator and Narratee

The article deals with some pragmatic parameters of Ukrainian-language culinary site as a special genre in the communicative space of Internet. It is a 
specific electronic dynamic cookbook existing in the socio-communicative situation of the transfer (dissemination) of experience. The communicative purpose of the culinary sites is through the selection and presentation of recipes relaying culinary experience, attracting a wide range of recipients to culinary art, forming a positive evaluative attitude to food and cooking as an important part of social and cultural life of the person. Authors of culinary sites are keen to encourage recipients to culinary experimentation, promote the idea of healthy homemade food and nutrition.

The generalized images of a narrator (author) and narratee (recipient) of Ukrainian culinary sites are described. The typical author is not a professional cook or shef, but an experienced mistress who shares her experiences and secrets of home cooking, recipes of dishes, personally tested and proven. Home cooking is presented as an important factor in a happy family life, joy and pleasant emotions.

It has been found that culinary sites are intended for a wide range of recipients, but the main target audience is women. There are two main groups of narratees. The first group contains experienced cooking lovers, amateur cooks tending to vary their daily meals, expand their culinary experience. The second one consists of novices, beginners who want to learn how to cook delicious dishes quick and easy to prepare - at home.

Key words: culinary site, speech genre, communicative purpose, narrator, narratee.

\section{Постановка проблеми, аналіз наукових публікацій.} Кулінарний (гастрономічний, глютонічний) дискурс як комплексне явище, мовленнєва діяльність та породжувана в ній різноманітність текстів потрапив до кола уваги філологів не так давно. Цей дискурс пов'язаний зі сферою виробництва та споживання їжі, що, зі свого боку, є однією з ключових умов життя людини й людства загалом, задовольняє вітальну потребу людини в харчуванні. Кулінарія - це передусім простір буденності, повсякденності, звичних практик життєдіяльності, сформованих під впливом соціально-культурного оточення. Практики харчування традиційно були предметом зацікавлення антропологів та етнографів, а також темою філософських міркувань (див., наприклад, широко відомі "Міфологіки" К. Леві-Стросса [Levi-Stross / Леві-Стросс 2000], статтю C. Яценка “Традиційна народна їжа як предмет етнографічного дослідження” [Yatsenko / Яценко 2006], огляд О. Варипаєва про філософське осмислення їжі та харчування [Varypaiev / Варипаєв 2012]). Наприкінці XX - на початку XXI століття подібна тематика зацікавила соціологів (див., наприклад, 
докторську дисертаційну працю В. Ніколенка [Nikolenko / Ніколенко 2015]).

Українські лінгвісти традиційно вивчали різноманітні групи лексики, пов'язані зі сферою харчування: назви продуктів харчування, страв, кухонного начиння тощо - на матеріалі загальнонародної розмовної мови, словників, діалектного мовлення, певних груп кулінарної термінологічної лексики (розвідки Л. Борис, Е. Гоци, 3. Козирєвої, О. Крижко, Н. П’яст, С. Руденко, Л. Славової, Л. Струганець, С. Яценка). 3'являються поодинокі праці, присвячені лінгвосеміотичному, лінгвокультурологічному, етнолінгвістичному, комунікативнопрагматичному аналізу мовних одиниць, які репрезентують сферу кулінарії (В. Жайворонок, О. Малюк, С. Руденко). Але поки що відсутнє комплексне дослідження українського кулінарного дискурсу, яке репрезентувало би всі аспекти цього явища у їх взаємозв'язку. Окрім того, із розвитком матеріальної культури, поглибленням і розширенням міжкультурної взаємодії внаслідок глобалізації, із появою та стрімким розвитком нових способів, каналів і засобів комунікації досить швидко змінюється і сам кулінарний дискурс, у якому, зокрема, формуються нові мовленнєві жанри. Подібні новації також поки не знайшли свого висвітлення в наукових розвідках.

Мета й завдання дослідження. Наше дослідження присвячене одному 3 новітніх жанрів кулінарного дискурсу кулінарному сайту. Предметом розгляду стали деякі прагматичні характеристики двадцяти українських кулінарних сайтів (звернення до них охоплюють період січень - квітень 2019 р.). Мета статті - характеристика ключових прагматичних параметрів українського кулінарного сайту: соціальнокомунікативну ситуацію, комунікативну мету, образи адресанта й адресата.

Виклад основного матеріалу. Відразу зробимо кілька важливих зауважень щодо об'єкта та матеріалу дослідження. Проблема класифікації мовленнєвих жанрів, виявлення їх власне мовних та комунікативно-прагматичних характеристик не $\epsilon$ новою в лінгвістиці. Беручи витоки у працях М. Бахтіна, жанрознавство наразі активно вивчає жанрову специфіку 
Інтернет-комунікації. Дослідники підкреслюють, що Інтернет створює особливий комунікативний простір, у якому зазнають трансформації традиційні жанри усної й писемної комунікації, а також формуються нові жанри, до класифікації яких немає єдиного підходу [Goroshko / Горошко 2015 : 120]. Не вдаючись до детального аналізу доволі широкого спектру публікацій, присвячених означеній проблемі (див., наприклад, роботи О. Горошко, В. Дементьєва, О. Жигаліної, О. Землякової, С. Іщук, Л. Капанадзе, Л. Компанцевої, С. Матвєєвої, Т. Полякової, Є. Савчук, К. Седова, Л. Щипіциної), виділимо ключові моменти, на яких акцентують дослідники, говорячи про сайт: це особливий жанр, який виник у мережі Інтернет; складний жанр, своєрідне макроутворення (перспективним видається термін "гіпержанр" ([Goroshko / Горошко 2010]); основними структурними компонентами сайту є веб-сторінки; сайт органічно поєднує різні форми та способи передачі інформації: вербальні, аудіальні, візуальні; сайт є динамічною макроструктурою; сайт функціонує в багатьох жанрових варіантах залежно від комунікативної мети, тематики, композиційних, мовно-стильових особливостей (жанрові різновиди сайтів із погляду їх комунікативно-мовної організації тільки починають описуватися (див., наприклад, роботу С. Матвєєвої [Matvieieva / Матвєєва 2006]). Отже, під сайтом розуміємо складне багаторівневе динамічне макроутворення в комунікативному просторі Інтернету, яке реалізує визначену комунікативну мету через певним чином впорядковану сукупність веб-сторінок.

Кулінарний сайт являє собою особливий тип сайту, який може бути виокремлений на основі сукупності традиційних критеріїв (праці Ф. Бацевича, В. Дементьєва, Н. Кравченко, О. Селіванової, Т. Шмельової та ін.), низки нових, пов'язаних зі своєрідністю взаємодії в комунікативному просторі Інтернету, а саме: соціально-комунікативна ситуація, комунікативна мета, концепції адресанта й адресата, зміст повідомлення, часові параметри, композиційна побудова, мовно-стилістичні особливості, інтерактивність, креолізованість. Охарактеризуємо перші три параметри українськомовного кулінарного сайту. 
Соціально-комунікативна ситуація. За "Словником української мови”, “ситуація - сукупність умов і обставин, що створюють певне становище, викликають ті чи інші взаємини людей” [Slovnyk / Словник 1978: 208]. Соціальнокомунікативну ситуацію, яка лежить в основі породження специфічного Інтернет-жанру кулінарного сайту, можна загалом охарактеризувати як “обмін досвідом" чи “поширення (передача) досвіду”. 3 одного боку, маємо різні потреби, інтенції особи у сфері іiі кулінарної компетентності: бажання приготувати нову страву, оновити чи модифікувати давно відому рецептуру, уточнити склад інгредієнтів чи умови приготування, прагнення здивувати гостей, випробувати власну кулінарну майстерність, удосконалити навички й т.ін. Усе це спонукає особу передусім до пошуку необхідної інформації, а після цього - до конкретних дій. 3 другого, - інша особа (особи) реалізується як носій знання й досвіду, котрий має намір ними поділитися, допомогти іншим у їхніх кулінарних пошуках, ретранслювати певні традиції й цінності, пов'язані зі сферою кулінарії тощо. Із третього, - наявний інструментарій - у нашому разі не тільки знаковий (мова й інші знакові системи), а й технічний і програмний (комп'ютерна техніка та програмне забезпечення, комп'ютерні мережі), - який дозволяє реалізувати інтеракцію i яким володіють учасники комунікації. Саме технічний і технологічний компоненти впливають на видозміну часових i просторових параметрів комунікації: доступ до інформації на сайті можливий будь-де й будь-коли за умови наявності відповідних пристроїв і доступу до мережі Інтернет. Комунікація виявляється асинхронною, без чіткої часової залежності [Savchuk / Савчук 2010 : 164-165]. I, звичайно ж, наявний певний обсяг кулінарного знання як соціокультурного феномена, засвоєного через індивідуальну практику та досвід, унаслідок цього перевіреного, апробованого, оціненого й часто модифікованого.

Комунікативна мета. Дуже загально кулінарний сайт може бути охарактеризований як своєрідний Інтернет-варіант кулінарної книги, Інтернет-збірник рецептів. На сайті акумулюється, систематизується, класифікується інформація 
щодо приготування страв. Окрім суто утилітарного завдання допомогти розв'язати буденну проблему “що приготувати” або “що будемо сьогодні їсти”, подати рецепт для приготування тої чи тої страви, - кулінарний сайт покликаний сформувати у відвідувачів (читачів) уявлення про кулінарію як мистецтво, опанувати яке здатен кожен, і про важливість смачної, корисної, приготованої власноруч їжі для різних аспектів соціального буття людини. Основну комунікативну мету кулінарного сайту вбачаємо в ретрансляції кулінарного досвіду як певної соціокультурної цінності.

На авторських кулінарних сайтах потрапляємо пряму вербалізацію намірів і мети мовця. Так, Євген Клопотенко на головній сторінці свого сайту рецептів, звертаючись до відвідувачів, заявляє про прагнення змінити їх ставлення до кулінарії: Мені хочеться, щзоб ви змінили своє ставлення до їжі та ї̈ приготування <..> Впевнений, що мої ідеї та поради обов'язково допоможуть вам зробити своє харчування ціккавим $i$ смачним (11). Є. Клопотенко вбачає свою мету в тому, щоб навчити пересічну людину готувати смачно й швидко із доступних продуктів і володіючи мінімальними кулінарними навичками: На моєму сайті ви знайдете сотні рещептів на кожен день, простих у приготуванні <..> Для кулінарних шедеврів на вамій кухні не потрібні лобстери або устричі, складні техніки приготувань $i$ багато часу (11). Авторка кулінарного сайту "Пані Стефа", львівська блогерка Маріанна Душар, прагне не просто зберегти стародавні рецепти, а й підвищити загальну кулінарну культуру: Хочу, щоб люди споживали їжу усвідомлено $і$ смакуючи <..> Хочу, щุоб кулінарна культура полягала <..> в розумінні прочесів, які відбуваються на пательні чи в баняку (не кажучи вже про організм, це я вже розмріялася). Хочу, щоб з нашого столу не зникали наїдки наших бабусь, а з лексикону - їхні назви (9). Автор та адміністратор сайту "Катрусина кухня" презентує його як один із засобів, що дасть змогу будь-якій людині розкрити закладений у ній кулінарний талант, знайти натхнення i приготувати не просто страву, а "кулінарне творіння": Більшою чи меншою мірою у кожній людині є талант до кулінарного

(с) О. Остроушко, 2019. 
мистецтва, а цей сайт - один із засобів, що може допомогти вам його розкрити (5). Сайт "Shefkuhar.com.ua" покликаний спонукати читачів до приготування страв, щоб принести радість і собі, і близьким, подарувати позитивні емоції й приємні спогади, розкрити свій потенціал кулінара-творця: Радуйте себе! Радуйте своїх близьких! Радуйте один одного! Цей кулінарний сайт послужсть імпульсом для Вашої фантазії, $і$ в приготуванні своїх кулінарних шедеврів Ви зможете втілити весь свій творчий потенціал і проявити всі грані свого таланту (18).

Усі сайти дозволяють відвідувачам залишати коментарі до вміщених матеріалів, а деякі (як-от, "Shefkuhar.com.ua" (18) та "Пательня" (10) - надають змогу додати на сайт і власний рецепт як окремий допис. Такі можливості зворотного зв'язку, діалогічності й полілогічності сприяють реалізації кількох завдань: оцінити рецепт або готову страву, репрезентувати й поширити власний кулінарний досвід, спонукати до кулінарного експериментування.

Концепції адресанта й адресата. Аналізовані кулінарні сайти можемо чітко поділити на дві групи: до першої належать авторські сайти, другу групу доцільно назвати “анонімними” це сайти, які або адмініструються певною групою осіб (як-от сайт "Пательня": Адміністрація підпорядкована та здійснює свою діяльність в межах роботи ПП “Арт-комплекс” (10), або на сайті взагалі відсутня інформація про авторів дописів чи адміністраторів (наприклад, сайти “Мій кулінар" (8), “Їсти” (4), "RECEPTYstrav" (16), сайт "Varenyk.com" (20), на якому в інформації про застереження щодо авторських прав указано лише електронну адресу видавця, чию згоду необхідно отримати для використання розміщених на сайті матеріалів). Ця друга група сайтів - серед проаналізованих їх трохи більше половини (11 із 20) - справді подібна до знеособленого електронного збірника рецептів. Можна лише припустити, що анонімні автори дописів компетентні в питаннях приготування їжі та харчування, оскільки в початкових коментарях до рецептів так чи так обгрунтовують його вибір. Представляючи рецепт Італійського салату з тунцем та маринованим болгарським перием, дописувачі сайту “Їсти” уживають авторське ми, 
загальноприйняте як нормативне в науковому спілкуванні, дають оцінку смаковим якостям продуктів, їх харчовій цінності, затратам часу, необхідного для приготування, корисності страви для організму: Тунець не лише корисний, але й дуже смачний, та малокалорійний - тому він стане прекрасним інградієнтом для різноманітних салатів. Їсти.сот.иа представляє для вас рецепт надзвичайно ситного салату з кисло-солодким болгарським перчем та шматочками консервованого туния. Цей салат дуже швидкий у приготуванні (підготувати слід тільки яйчя, попередньо зваривши їх) та легкий для травної системи, адже заправлясться не майонезом, а оливковою олією (4). Таку саму невизначену множину ми спостерігаємо на сторінці “Про сайт рецептів" сайту “Готуємо разом!”: ми - група людей, яка створила сайт, адмініструє його, 3 якими можна поспілкуватися, написавши листа на вказану адресу електронної пошти; це ті люди, 3 допомогою яких можливо підвищити рівень домашньої кулінарії: 3 нами трьохповерховий випечений шедевр у духовиі може стояти і на вашому столі! (1)

Авторські кулінарні сайти, а також кулінарні блоги (як-от “Кулінарні варіації вар'ятки" (7)) (9 із 20 проаналізованих) містять окрему веб-сторінку з інформацією про автора дописів (адміністратора сайту), а саме: фото, ім'я, професія (освіта, рід занять), відношення до кулінарії, мета кулінарної діяльності, причини створення сайту і його мета, стисла характеристика сайту, звернення до відвідувачів (читачів). Ці змістові елементи розкриваються різною мірою, деякі можуть бути відсутні. Скажімо, авторка сайту "Пані Стефа" на сторінці "Про мене" поряд із фото говорить лише про своє ставлення до кулінарії та про цілі, яких прагне досягнути, створюючи дописи на сайті (9). Власне, не вказано й імені авторки, яке довідуємося, скориставшись гіперпосиланням на сторінку спільноти "Пані Стефа" у соціальній мережі Facebook, де в розділі "Інформація" $\epsilon$ чергове покликання на особисту сторінку. Відвідувачі сайту в коментарях, звертаючись до автора, уживають псевдонім. Але популярність сайту, про яку, зокрема, свідчить i множина коментарів до дописів із високими позитивними оцінками, спричинила відкриття справжньої особистості автора: їй

(c) О. Остроушко, 2019. 
присвячено публікацію в інтернет-виданні "Українська правда" [Markovska / Марковська 2018].

Серед проаналізованих сайтів лише один належить професійному кулінару - це сайт рецептів Євгена Клопотенка (11). На окремій сторінці шеф-кухар подає біографічну інформацію про події в житті, що виявилися важливими для його становлення як професіонала, про основні види професійної діяльності та зростання, про участь у різних заходах i проектах, значущих для набуття кулінарного досвіду. Є. Клопотенко говорить про головну мету свого життя поліпшити культуру харчування в нашій краӥні; підкреслює, що готовий із усіма ділитися досвідом і кулінарними секретами: $я$ люблю ділитися знаннями, а не зберігати їх в собі; закликає читачів у дивовижний світ кулінарного мистецтва для спільної діяльності: давайте разом готувати, пізнавати нове, ділитися своїми досягненнями $i$ невдачами, просто спілкуватися. Важливою виявляється інформація про різноманітні бізнеспроекти, участь у телевізійних шоу та професійна діяльність як ресторатора. Створенню образа досвідченого кулінара, якому можна беззастережно довіряти, сприяють лексеми з позитивною оцінною семантикою: переможець кулінарного шоу, кулінарний експерт, бренд-иеф (11).

Авторами й адміністраторами усіх інших сайтів є люди, для яких кулінарія - захоплення, улюблена справа, щоденна робота на домашній кухні, готування для сім’і $\mathrm{i}$ т.ін. I в абсолютній більшості це жінки: із дев'яти досліджених авторських сайтів лише два - Є. Клопотенка (11) і сайт “Шмакота!" (12) - належать чоловікам. Щодо останнього, сайт не оновлюється з 2015 року, чому є надзвичайно сумне й гірке пояснення: його автор загинув під час військових дій на Донбасі, про що довідуємося 3 головної сторінки сайту, де представлений рецепт коктейлю під назвою “Слава Україні! ”, супроводжуваний епіграфом Саме цей пост на сайті був би першим після того, як автор повернувся б з війни. Але він останній... Дружина автора. На веб-сторінці "Про сайт" наявний авторський текст, викладений від 1-ої особи однини, у теперішньому часі, тож припущення про те, що автор - 
чоловік, можна було зробити лише 3 огляду на добір представлених на сайті рецептів, серед яких переважна більшість - алкогольні коктейлі, а також із початкових коментарів до рецептів, у яких подекуди вживається родова форма минулого часу: Щось подібне до такого супу я ї в Болгарії (до рецепту “Томатний крем-суп” (12)).

Типовий автор українського кулінарного сайту - молода заміжня жінка, мати, для якої кулінарія - захоплення й уміння, що бере свої витоки 3 дитинства. Це жінка, що полюбляє готувати для рідних і близьких, яку підтримує родина в іiі кулінарних пошуках, дає оцінку стравам, допомагає у веденні сайту. Любов до найрідніших стає поштовхом для того, щоб через приготування смачної страви виразити це почуття й подарувати не просто насолоду від споживання, а відчуття щастя. Домашня кулінарія створює сімейний затишок, гуртує родину, дарує радість і від спільної роботи, і від сімейної трапези, i від спілкування. Успіхи на домашній кухні підштовхують до того, щоб поділитися знаннями і вміннями 3 іншими. Так, авторка сайту "Рicante Cooking" Вікторія Попін, за професією юрист міжнародного права, говорить: Любов до чоловіка та наших донечок, надихає готувати смачні страви, рухатись вперед та надихати своїм прикладом інших (15). I чоловік, і доньки долучаються до справи готування й ведення сайту. Вона акцентує: Моєю філософією є те, щзо завдяки смачним стравам, гарно прибраному столу, традиціям, що ми створюємо самі, можна отримувати частинку щастя кожного дня ци щоденно почувати себе щзасливішим <..> Приємні смакові відуття збагачують нас і роблять щасливішими (15). Авторка сайту "ТandiCOOK” про себе лише зазначає, що вона мама і дружина, але підкреслює, що полюбляє готувати для рідних, що $\epsilon$, на іiі погляд, органічним для жінки: Мене звати Оля - я мама і дружина. Як кожна жінка я полюбляю тішити своїх рідних різними смаколиками (19). "Господиня" сайту "Smachno.in.ua" (як вона сама про себе говорить), Люба, також описує допомогу чоловіка й доньки у веденні сайту, але робить акцент на кулінарії як творчості та іï естетичній складовій: $B$ моїй праці мені подобається саме те, щуо я маю змогу показати

(C) О. Остроушко, 2019. 
своє ставлення до приготування їсі - як до захопливої гри, експерименту, творчого прочесу <... \ Перефразовуючи Чехова, в їжі все повинне бути красиво:) (17). Авторка блогу “Кулінарні варіації вар'ятки”, журналістка Ольга, зазначає, що кулінарія невід'ємна частинка ії життя, а “Кулінарні варіації вар'ятки” це блог про смачне життя, про те як можна легко і просто зробити свої будні смачними та неповторними (7).

Представлені на авторських сайтах рецепти випробувані й перевірені, що підтверджується, зокрема, фотографіями процесу приготування, вступними коментарями тощо. Так, даючи загальну характеристику Пирогу з консервованими фруктами, авторка сайту "Катрусина кухня" пише: У даному випадку $я$ використовувала перетерті яблука. Вийшло дуже круто! (5) До рецепту Спагетті з овочами і соєвим соусом по-тайськи зазначено: Саму ідею підказала мені моя сестричка, яка готувала иңю страву для себе, а я вже ї випробувала, підлаштувала під свої потреби і смаки, і вийшло те, що ви зараз бачите на картинщі (5). Переписи на сайті "Пані Стефа" містять розлогі вступи, які стосуються історії страви, іï національних особливостей, своєрідності подачі, відмінностей у рецептурі тощо, але авторка подає варіант рецепта, за яким готувала сама: наприклад, оповідаючи про Шакшуку, або “саджені яйия на левантійський манер”, блогерка завершує: Ото почитавии про шакшуку, я зрозуміла, що можу зробити ї̈ собі з чого завгодно, тому відразу кажу - на автентичність не претендую, але це так, як я ї̈ приготувала останнього разу (9). Авторки сайтів "Picante Cooking", "Smachno.in.ua", блогу "Кулінарні варіації вар'ятки" на веб-сторінках із загальною інформацією про себе i про сайт підкреслюють, що всі описувані страви були приготовлені власноруч. Наприклад, Вікторія Попін зазначає: Тут я пишу про випробувані $i$ перевірені мною методи приготування, про кулінарні хитрощі $i$, звичайно ж, публікую свої найкращі рецепти. Те, що мені не вдалось, Ви тут не знайдете (15). Авторка блогу “Mira Fild”, Мирослава Павлючок, до кожного з рецептів додає стислу розповідь про власні спроби приготування презентованої страви, часом це історії 3 особистого життя, пов'язані зі стравою, як-от щодо допису 
Із серії смачних сніданків “Сирники”: важливими виявляються дитячі спогади про страву ( $B$ мене вони асоціюються 3 дитинством. Дуже часто мама готувала нам їх на сніданок, коли ми йшли в школу), набуття досвіду в їх приготуванні в студентські роки (3 початком студенського життя, я сама навчилася готувати сирники, $i$ до четвертого курсу вже увійшло в привичку, хоча б раз в тиждень снідати ними), як вагомий аргумент на користь пропонованого рецепта наводиться авторитетна оцінка професіонала ( $А$ одного разу ... $\ddot{x}$ спробував шеф $i$ казав, щзо смачні) (13). Презентація рецепта страви як особисто перевіреного й оціненого створює атмосферу довіри й переконання в тому, що й адресат спроможний досягти такого ж результату, просто чітко дотримуючись викладених рекомендацій і не витрачаючи часу на вдосконалення базового рецепта.

Кулінарні сайти представляють домашню кулінарію, рецепти, призначені для використання на домашній, не професійній кухні. При цьому типовим $є$ акцентування на високих смакових якостях домашніх страв, до яких не можуть дорівнятися заклади громадського харчування і передусім так званий фастфуд. Готувати й харчуватися вдома - це не тільки смачно, але й корисно. Так, автори сайту "Готуємо разом!" беззастережно заявляють: Більшість людей обирає домашню кухню - адже це ідеальний варіант здорового та надзвичайно смачного харчування. Говорять, що сайт створений передусім саме для почіновувачів домамніх страв (1). А на головній сторінці сайту "РapiGutto" натрапляємо на твердження про те, що готувати самостійно (а особливо здорову їжу) стає модно (14).

Серед широкого кола адресатів кулінарних сайтів відразу чітко виділяються дві групи. Перша - це вже згадані поціновувачі домашньої кулінарії, ті, хто полюбляють готувати вдома різноманітні страви, любителі кулінарного мистецтва. Так, ті, хто вміє і любить готувати, - перша цільова аудиторія сайту "Мій кулінар" (8). Другу групу складають новачки на домашній кухні, ті, хто не має достатніх навичок готування, але прагне навчитися. Вікторія Попін, характеризуючи свій сайт "Picante Cooking", заявляє, що опрацьовує рецепти так, щоб 
з ними міг готувати кожен. Як новачок, так $i$ досвідчений кулінар (15). Так само авторка "Катрусиної кухні" говорить, що на сайті представляє як прості рецепти, так і складніші та вишуканіші страви, тому сподівається, що на сайті буде комфортно всім - як початківцям, так $і$ більш досвідченим кулінарам (5). Максимально широко уявляють свого адресата й автори сайту "РapiGutto": На нашому сайті збираються професійні кухарі й новачки, гурмани й епікурейці, цінителі екзотичних страв і збирачі рецептів (14).

3 огляду на ці дві основні групи адресатів, кардинально різних за рівнем своєї кулінарної вправності та майстерності, а також зважаючи на наявність між ними низки інших - не дуже навчених, менш досвідчених, не дуже досконалих тощо - на сайтах може подаватися інформація щодо складності рецепта, як-от на сайті "Varenyk.com": легко, середній (20); на сайті "Пательня": елементарно, легко, складно (10); на сайті "Кукорама": легко, нормально, складно (6). Кулінарам-новачкам призначені й коментарі до деяких рецептів, покликані переконати початківців у легкості приготування страви. Наприклад, Є. Клопотенко так коментує рецепт Рулет 3 телятини зі шпинатом і горіхами: М'ясний рулет - страва, яку багато хто вважає чимось дуже складним, але це абсолютно не так. <..> Мінімум інгредієнтів, максимум смаку $i$, як завжди, дуже просто (11). А в блозі "Кулінарні варіації вар'ятки" Американське печиво з шоколадними краплями охарактеризовано як надзвичайно смачне та просте в приготуванні (7). Автори рецептів часом указівку на простоту виносять у назву рецепта, як-от Салат “Цезар” по-простому (19).

Яким би не був адресат за рівнем своєї кулінарної майстерності, він уявляється людиною зайнятою, яка не має багато часу на стояння біля плити, через що швидкість приготування страви - одна 3 важливих характеристик пропонованих рецептів. На сайті “ТandiCOOK" (19) натрапляємо на добірку Весняні салати: 5 простих та швидких рецептів; авторка "Катрусиної кухні" в рецепті Запіканки з молодих кабачків зауважує позитивну сторону будьякої запіканки: Істотний бонус кожної запіканки - чи це сирна, 
чи овочева, чи якась інша, - в економії часу $\boldsymbol{i}$ простоті приготування (5). Як дуже прості та швидкі у приготуванні характеризуються Курячі фрикадельки зі шпинатом на пару на сайті "Picante Cooking" (15). Простота, швидкість приготування поряд із гарним смаком готової страви та іï вишуканістю (у контексті досліджуваного матеріалу це передусім означає небуденність страви, можливість подати ії до святкового столу) - таке поєднання характеристик виявляється найбільш оптимальним: Паштет з оселедия - проста та водночас вишукана закуска, яка готується всього 15 хвилин (сайт "Їсти" (4), рецепт Паштет з оселедия). Вказівка на часові характеристики може міститися в назві рецепта: Печиво за 15 хвилин! (19), позитивної оцінки набуває прислівник нашвидкуруч (щоправда, автори часто роблять орфографічну помилку в його написанні): в означальній функції в назві рецепта означає “швидко”, “без зайвих зусиль”: Рагу з кабачків нашвидкоруч (6); Піцуа нашвидкоруч (3).

Адресат кулінарних сайтів уявляється людиною не дуже заможною, тому доступність і відносна дешевизна продуктів також важлива характеристика пропонованої страви й вагомий чинник, аби спробувати приготувати за тим чи тим рецептом. Так, на сайті "РарiGutto" знаходимо добірку Найпростіших рецептів салатів без майонезу, які і приготувати можна за декілька хвилин, та інгредієнти до яких в жодному випадку не є рідкісними та дорогими, тобто делікатесними продуктами (14). На сайті “Кукорама” м'ясна страва Строганка з гірчицею презентується як така, що готується вона доволі легко та швидко, з абсолютно звичайних продуктів (6).

Гендерні аспекти виявляються важливими i в характеристиці адресата. Кулінарні сайти призначені передусім для жінок: Кожна господиня протягом літа та осені намагається зробити чим по більше запасів на зиму (19); навіть досвідчені господині іноді потребують підказок (14); Животики сьомги - гарний варіант для економних господинь (рецепт Суп iз животиків сьомги на сайті "Кукорама" (6). I хоч автори більшості дописів намагаються уникнути гендерного маркування, уживаючи форми 2-ої особи множини (і займенник

() О. Остроушко, 2019. 
“Ви” Якщо вам подобається смажена риба... (рецепт Стейк з лососю на пергаменті, сайт Є. Клопотенка (11) й означеноособові синтаксичні конструкції на кшталт Приготуйте - не пошкодуєте!; Спробуйте наш рещепт (1), усе одно в описових коментарях там чи там вербалізується уявлення про те, що домашня кулінарія - жіноча справа. Але це та справа, яка отримує надзвичайно високу оцінку: Найкраща кухня домашня, найсмачніші наїдки - від мами та бабусі (вступ до розділу "Гарячі страви: рецепти до столу" на сайті “Їсти" (4). Адресат кулінарних сайтів - жінка-господиня, яка прагне через готовані страви не просто наситити родину, а й створити гарний настрій, подарувати радість. Це жінка-господиня, що турбується про різні аспекти домашнього господарювання (доступні недорогі продукти, швидкість приготування) та здоров'я близьких (поживність страви, іiі корисність). Готова до експериментування й прагне урізноманітнити щоденне харчування в сім’ї.

Водночас чоловіки не лишаються осторонь “кухонних справ”. Уся родина, і насамперед чоловік господині, постають не сторонніми спостерігачами, а помічниками й активними учасниками процесу готування. До прикладу, Люба, "господиня" сайту "Smachno.in.ua", пише про важливу роль свого чоловіка: Юрко теж допомагає мені в приготуванні страв для сайту. Правда, трапляється це нечасто, бо його основне завдання - це фото. Але я знаю, щуо він неперевершений у мистецтві приготування особливо італійських страв. Саме його лазанью, соус песто, томатний соус з базиліком $і$ m. n. ви мали (або маєте) нагоду бачити у нас (17). Нечасто, але потрапляємо на сайтах рецепти, призначені для чоловічої частини аудиторії, як-от Вечеря для двох: pецепт запеченої качки з картоплею на сайті “Їсти”: Запросили дівчину в гості на вечерю? Хочете ї̈ здивувати? Давайте разом $з$ вами приготуємо смачну романтичну вечерю на двох... Зваблювати будемо запеченою качкою з картоплею (4).

Кулінарні сайти створені для якнайширшої аудиторії: від людини, яка шукає рецепт страви нашвидкуруч, до тих, хто полюбляє куховарити вдома й експериментувати з новими 
стравами. Це електронні ресурси для звичайних, пересічних людей, які бажають унести різноманіття у своє щоденне харчування, отримати від куховарства позитивні емоції та подарувати їх близьким.

Висновки та перспективи подальших наукових розвідок. Кулінарні сайти становлять окремий жанровий різновид у комунікативному просторі Інтернету. Соціальнокомунікативну ситуацію їх функціонування можемо охарактеризувати як “передача досвіду”. Комунікативна мета кулінарних сайтів - через добір і презентацію рецептів приготування страв ретранслювати кулінарний досвід, залучати широке коло адресатів до кулінарного мистецтва, формувати позитивне оцінне ставлення до їжі й кулінарії як важливої частини соціально-культурного буття людини. Типовим автором українського кулінарного сайту $\epsilon$ не кухар-професіонал, а досвідчена господиня, котра ділиться своїм досвідом i секретами домашнього куховарства. Кулінарні сайти призначені широкому колу адресатів, але основною цільовою аудиторією залишаються жінки.

У подальшому потребують аналізу та опису інші параметри українських кулінарних сайтів, зокрема їх змістове наповнення та композиційна побудова, часові параметри, мовно-стилістичні особливості, своєрідність інтеракції адресанта й адресата 3 огляду на характеристики Інтернетпростору, креолізованість текстів.

\section{Література}

1. Варипаєв О. М. Філософія їжі: концептуальні підходи до осмислення феномену Економічна стратегія і перспективи розвитку сфери торгівлі та послуг. Харків, 2012. Вип. 1 (2). С. 319-325.

2. Горошко Е. И, Жигалина Е. А. Виртуальное жанроведение: устоявшееся и спорное. Вопросы психолингвистики. 2010. № 12. С. 105-123.

3. Горошко Е. И., Полякова Т. Л. К построению типологии жанров социальных медий. Жанры речи. 2015. № 2 (12). С. 119-127.

4. Леви-Стросс К. Мифологики : в 4 т. Москва ; Санкт-Петербург : Культурная инициатива ; Университетская книга, 2000. Т. 1: Сырое и приготовленное / пер. 3. А. Сокулер, К. З. Акопян. 406 с.

5. Марковська М. Пані Стефа - про галицьку кухню, смакові спогади та ритуали. Українська правда. 2018. 12 серпня. URL : https://ife.pravda.com.ua/ society/2018/08/12/232637/ (дата звернення: 10.03.2019)

(C) О. Остроушко, 2019. 
6. Матвєєва С. А. Сайт як жанр Інтернет-комунікації (на матеріалі персональних сайтів учених) : автореф. дис. ... канд. філол. наук : 10.02.15 / Донецький національний університет. Донецьк, 2006. 19 с.

7. Ніколенко В. В. Гастрономічні детермінанти суспільного життя: соціологічний вимір : дис. ... д-ра соціол. наук : 22.00.01/ Дніпропетровський національний університет імені Олеся Гончара. Дніпропетровськ, 2015. 441 с.

8. Савчук С. О. Мовні жанри у Всесвітній павутині: методологічні основи класифікації. Компаративні дослідження слов'янських мов і літератур. Київ, 2010. Вип. 12. С. 160-169.

9. Словник української мови : в 11 т. / АН Української РСР, Ін-т мовознав. ім. О. О. Потебні ; редкол.: І. К. Білодід (голова) [та ін.]. Т. 9 : С / ред. тому: I. С. Назарова [та ін.]. Київ : Наук. думка, 1978. 916 с.

10. Яценко С. А. Традиційна народна їжа як предмет етнографічного дослідження. Вісник Житомирського державного університету ім. I. Франка. 2006. Вип. 28. С. 233-236.

\section{Список джерел}

1. Готуємо разом! URL : http://gotuemo.com

2. Готуємо разом! Найкращі рецепти українською. URL : http:/gotyemo.pp.ua

3. Домашні кулінарні рецепти. URL : https://recepts.in.ua

4. Їсти! URL : https://jisty.com.ua

5. Катрусина кухня. URL : https://easy-cooking.com.ua

6. Кукорама. URL : https://cookorama.net/uk

7. Кулінарні варіації вар'ятки. URL : http://olvenkylinar.blogspot.com

8. Мій кулінар. URL : http://www.miykulinar.ru

9. Пані Стефа. URL : https://panistefa.com

10. Пательня. URL : http://patelnya.com.ua

11. Сайт С. Клопотенка. URL : https://klopotenko.com/uk/

12. Шмакота! URL : http://shmakota.com.ua

13. Mira Fild. URL : http://myroslavapavliuchok.blogspot.com

14. PapiGutto. URL : https://papigutto.com.ua/ua/

15. Picante Cooking. URL : https://picantecooking.com/ua/

16. RECEPTYstrav. URL : http://receptystrav.com.ua

17. Smachno.in.ua. URL : https://www.smachno.in.ua

18. Shefkuhar.com.ua. URL : https://shefkuhar.com.ua

19. TandiCOOK. URL : https://tandicook.com.ua

20. Varenyk.com. URL : http://www.varenyk.com

\section{References}

1. Varypaiev O. M. Filosofiia yizhi: kontseptualni pidkhody do osmyslennia fenomenu Ekonomichna stratehiia i perspektyvy rozvytku sfery torhivli ta posluh. Kharkiv, 2012. Vyp. 1 (2). S. 319-325

2. Goroshko E. I, Zhigalina E. A. Virtual'noe zhanrovedenie: ustoyavsheesya i spornoe. Voprosy psiholingvistiki. 2010. № 12. S. 105-123

3. Goroshko E. I., Polyakova T. L. K postroeniyu tipologii zhanrov social'nyh medij. ZHanry rechi. 2015. № 2 (12). S. 119-127 
4. Levi-Stross K. Mifologiki : v 4 t. Moskva ; Sankt-Peterburg : Kul'turnaya iniciativa ; Universitetskaya kniga, 2000. T. 1 : Syroe i prigotovlennoe / per. Z. A. Sokuler, K. Z. Akopyan. $406 \mathrm{~s}$

5. Markovska M. Pani Stefa - pro halytsku kukhniu, smakovi spohady ta rytualy. Ukrainska pravda. 2018. 12 serpnia. URL: https://life.pravda.com.ua/ society/2018/08/12/232637/ (data zvernennia: 10.03.2019)

6. Matvieieva S. A. Sait yak zhanr Internet-komunikatsii (na materiali personalnykh saitiv uchenykh) : avtoref. dys. ... kand. filol. nauk : 10.02.15 / Donetskyi natsionalnyi universytet. Donetsk, 2006. $19 \mathrm{~s}$.

7. Nikolenko V. V. Hastronomichni determinanty suspilnoho zhyttia: sotsiolohichnyi vymir : dys. ... d-ra sotsiol. nauk : 22.00.01 / Dnipropetrovskyi natsionalnyi universytet imeni Olesia Honchara. Dnipropetrovsk, 2015. $441 \mathrm{~s}$.

8. Savchuk Ye. O. Movni zhanry u Vsesvitnii pavutyni: metodolohichni osnovy klasyfikatsii. Komparatyvni doslidzhennia slovianskykh mov i literatur. Kyiv, 2010. Vyp. 12. S. 160-169.

9. Slovnyk ukrainskoi movy : v 11 t. / AN Ukrainskoi RSR, In-t movoznav. im. O. O. Potebni ; redkol.: I. K. Bilodid (holova) [ta in.]. T. 9 : S / red. tomu: I. S. Nazarova [ta in.]. Kyiv : Nauk. dumka, 1978. 916 c.

10. Yatsenko S. A. Tradytsiina narodna yizha yak predmet etnohrafichnoho doslidzhennia. Visnyk Zhytomyrskoho derzhavnoho universytetu im. I. Franka. 2006. Vyp. 28. S. 233-236.

Стаття надійшла до редакиії 20.04.2019 р. Прийнята до друку 07.05. 2019 р. 